\title{
Far Upstream Element-Binding Protein 1
}

National Cancer Institute

\section{Source}

National Cancer Institute. Far Upstream Element-Binding Protein 1. NCI Thesaurus. Code C99616.

Far upstream element-binding protein 1 ( $644 \mathrm{aa}, \sim 68 \mathrm{kDa}$ ) is encoded by the human FUBP1 gene. This protein plays a role in the modulation of transcription. 